\title{
Variation of photosynthetic characteristics and yield in wild and cultivated species of yams (Dioscorea spp.) from Koraput, India
}

\author{
B. PADHAN and D. PANDA ${ }^{+}$ \\ Department of Biodiversity and Conservation of Natural Resources, Central University of Orissa, Koraput-764021, \\ Odisha, India
}

\begin{abstract}
Variations in leaf gas-exchange characteristics, PSII activity, leaf pigments, and tuber yield were investigated in seven wild and one cultivated species of Dioscorea from Koraput, India, in order to find out their overall adaptability to the environment. The leaf photosynthetic rate, transpiration, stomatal conductance, water-use efficiency, carboxylation efficiency, and photosynthetic pigments were significantly higher in some wild species compared to the cultivated species. In addition, some wild species showed better photochemical efficiency of PSII, photochemical quenching, and electron transport rate in comparison to cultivated one. Furthermore, leaf dry matter accumulation and tuber yield was also higher in some wild species compared to the cultivated species. Taken together, the wild species, such as D. oppositifolia, $D$. hamiltonii, and D. pubera, showed the superior photosynthetic efficiency compared to the cultivated $D$. alata and they could be used for future crop improvement programs.
\end{abstract}

Additional key words: chlorophyll fluorescence; gas exchange; photosynthesis; tuber yield.

\section{Introduction}

Root and tuber crops occupy a remarkable position towards food security of the developing world due to their high caloric value and carbohydrate content (Dansi et al. 1999, Kumar et al. 2013). Yam (Dioscorea) species are an important source of food and medicine in the tropics and subtropics and have a significant place in dietary habits of many rural and tribal communities (Edison et al. 2006, Behera et al. 2009). Dioscorea species are the monocotyledonous tuber crops from family Dioscoreacea; the genus includes more than 600 different species worldwide (Kouakou et al. 2010, Amanze et al. 2011). However, only few species are commercially cultivated and some wild edible species has not yet been domesticated due to inferior tuber quality, low yield, and transformable poisonous forms of some tubers (Behera et al. 2009). There is an enormous diversity in the wild and domesticated species that are being used by tribal communities (Dansi et al. 1999, Behera et al. 2009). However, systematic characterization of the diversity present in wild species is a major prerequisite for using it in breeding programs. As morphological description of Dioscorea plant is well established (Ngo Ngwe et al. 2015), its phenotyping based on photosynthetic traits could serve as a potential marker for varietal identification and differentiation in order to integrate them into developmental interventions.

Photosynthesis represents an integral part of the plant metabolism and balance sheet of growth and development, which is known to be regulated by internal and environmental factors (Gupta et al. 2002, Mathur et al. 2016). Photosynthetic rate of the entire crop canopy depends on

Received 24 August 2017, accepted 14 December 2017, published as online-first 17 April 2018.

${ }^{+}$Corresponding author; phone: 91-6852-251288, fax: 91-6852-251244, e-mail: dpanda80@gmail.com

Abbreviations: Car - carotenoids; $\mathrm{CE}-$ carboxylation efficiency $\left(=P_{\mathrm{N}} / C_{\mathrm{i}}\right) ; \mathrm{Chl}-$ chlorophyll; $C_{\mathrm{i}}-$ intercellular $\mathrm{CO}_{2}$ concentration; DM - dry mass; DMA - dry matter accumulation; $E$ - transpiration rate; ETR - electron transport rate; $F_{0}$ - minimal fluorescence yield of the dark-adapted state; $\mathrm{F}_{0}{ }^{\prime}$ - minimal fluorescence yield of the light-adapted state; $\mathrm{F}_{\mathrm{m}}$ - maximal fluorescence yield of the darkadapted state; $F_{m}{ }^{\prime}-$ maximal fluorescence yield of the light-adapted state; $F_{v} / F_{m}$ - maximal quantum yield of PSII photochemistry; FM - fresh mass; $g_{\mathrm{s}}$ - stomatal conductance; LSD - least significant difference; NPQ - nonphotochemical quenching; $P_{\mathrm{N}}-$ net photosynthetic rate; qp - photochemical quenching coefficient; RWC - relative water content; WUE - water-use efficiency $\left(=P_{\mathrm{N}} / E\right)$; $\Phi_{\text {PSII }}$ - effective quantum yield of PSII photochemistry.

Acknowledgements: Authors are grateful to the Head of the Department of Biodiversity and Conservation of Natural Resources for providing necessary facilities for the work and also grateful to University Grant Commission (UGC), New Delhi for providing NonNET Fellowship. Dr. Sanjay Ranjan, Application Scientist, Spectra Agritec, New Delhi, and Dr. R. K. Sarkar, Emeritus Scientist, ICAR-NRRI, Cuttack are highly acknowledged for their valuable suggestions. 
the photosynthesis of individual leaves (Below 2001), which can also be influenced by many plant factors, such as a leaf position and age, sink effects, mutual shading, as well as environmental factors, such as light, temperature, nutrition, and water availability (Rodríguez-Montero 1997, Aighewi and Ekanayake 2004). In vivo chlorophyll (Chl) fluorescence has been used frequently in the past as a convenient and nonintrusive method to determine the efficiency and estimate of photosynthetic performance of plants (Kao et al. 2003, Sayed 2003, Dudeja and Choudhury 2005). It allows to study functional photosynthesis indirectly at the pigment level, primary light reactions, thylakoid electron transport reactions, darkenzymatic stroma reactions, and slow regulatory processes (Batra et al. 2016). Pulse amplitude-modulated (PAM) fluorometer provides quantitative information about PSII (Souza et al. 2004) by measuring Chl fluorescence. The valuable information, such as electron transport rate (ETR), photosynthetic yield $\left(\mathrm{F}_{\mathrm{v}} / \mathrm{F}_{\mathrm{m}}\right)$, and quenching parameters, can be used to assess the performance of plants. The measurement of leaf pigmentation is an important parameter for eco-physiologists, because it is an indirect measure of nutrient status, which provides useful insights into plant-environment interactions (Elfeky et al. 2007). Unlike other plants, relatively few information has been published on the physiology and photosynthetic efficiency

\section{Material and methods}

Plant materials and growth conditions: The study was conducted with seven wild edible Dioscorea species, namely Dioscorea oppositifolia, D. tomentosa, D. hamiltonii, D. bulbifera, D. pubera, D. pentaphylla, and D. hispida along with one cultivated species, D. alata (Mishra et al. 2011). The tubers of wild Dioscorea species were collected from different forest patches of Koraput, while the cultivated species was collected from local farmer's field.

The experiment was conducted in the campus of Central University of Orissa, Koraput, India $\left(82^{\circ} 44^{\prime} 54^{\prime \prime} \mathrm{E}\right.$ to $18^{\circ} 46^{\prime} 47^{\prime \prime} \mathrm{N}, 880 \mathrm{~m}$ a. s. 1.; average rainfall of $1,500 \mathrm{~mm}$ ) during yam growing season (April-December) of 2015 and 2016. Plants were grown in $30-\mathrm{kg}$ polythene bags filled with mixture of farm soil and farmyard manure in a ratio of $3: 1$. The soil used for the experiment was deep loamy red and lateritic $(\mathrm{pH} 6.64$, organic $\mathrm{C}$ of $0.15 \mathrm{ppm}$, total $\mathrm{N}$ of $0.18 \mathrm{ppm}$, available $\mathrm{P}$ of $0.01 \mathrm{ppm}$, and available $\mathrm{K}$ of $0.84 \mathrm{ppm}$ ). Uniform-sized tubers of each species were selected and directly sown into the polythene bags by following the standard agronomic practices (Behera et al. 2009). The experimental design was a randomized block design with three replications in each species. Plants were regularly irrigated with tap water and subjected to natural solar radiation, with daily maximum PPFD, air temperature, and relative humidity of being about 1,560 \pm 20 $\mu \mathrm{mol}$ (photon) $\mathrm{m}^{-2} \mathrm{~s}^{-1}, 33.6 \pm 2{ }^{\circ} \mathrm{C}$, and $65-70 \%$, respectively. All the measurements were performed three times of tropical root and tuber crops and there is an information gap on photosynthetic differences between wild and cultivated species of Dioscorea. These eco-physiological traits of plants can be used to assess reliably the fitness and ecological dominance in plants.

Koraput is one of the thickly tribal $(\sim 65 \%)$ dominated districts of Odisha state in India, harbouring rich genetic diversity of tropical tuberous plants (Mishra et al. 2012); it has been recently declared as one of the agrobiodiversity hot spots in India (Mishra et al. 2012). There are seven wild Dioscorea species, such as Dioscorea oppositifolia, D. tomentosa, D. hamiltonii, D. bulbifera, $D$. pubera, D. pentaphylla, and $D$. hispida along with one cultivated species $D$. alata, which have been used as food by the tribal people of Koraput (Mishra et al. 2011, Padhan and Panda 2016). For proper utilization and incorporation of these wild Dioscorea species from the natural crop resources, identification of the allelic variants is of utmost importance. In this background, there is limited phenotypic knowledge and profiling reports of wild edible Dioscorea species in relation to their physiological efficiency. Identification of the variations in the physiological processes, such as leaf photosynthesis, PSII activity, and tuber yield, between the wild and cultivated Dioscorea species may help in yam improvement programs.

after $180 \mathrm{~d}$ of planting (in the flowering stage). Harvesting of tubers was done after all the vines dried which was around $240 \mathrm{~d}$ after planting. Fresh tuber yield of each plant was expressed as kg per plant. The pool data of different physiological and yield parameters of both the years 2015 and 2016 was presented.

Leaf gas exchange: The leaf gas-exchange parameters, such as net photosynthetic rate $\left(P_{\mathrm{N}}\right)$, transpiration rate $(E)$, intercellular $\mathrm{CO}_{2}$ concentration $\left(C_{\mathrm{i}}\right)$, and stomatal conductance $\left(g_{\mathrm{s}}\right)$ were measured between $10-12 \mathrm{~h}$ on fully matured leaves of each plant using an open system photosynthetic gas analyzer (CI-304, CID, USA) under normal ambient environmental conditions. The leaf from each plant was selected and kept inside the chamber under natural irradiance until stable reading was recorded. The measurements were carried out at $27 \pm 2^{\circ} \mathrm{C}, 60-70 \%$ of relative humidity, PPFD of $1,114 \pm 33 \mu \mathrm{mol} \mathrm{m} \mathrm{m}^{-2} \mathrm{~s}^{-1}$, $370 \mu \mathrm{mol}\left(\mathrm{CO}_{2}\right) \mathrm{m}^{-2} \mathrm{~s}^{-1}$, and $21 \% \mathrm{O}_{2}$. Leaf water-use efficiency (WUE, $P_{\mathrm{N}} / E$ ) and carboxylation efficiency (CE, $P_{\mathrm{N}} / C_{\mathrm{i}}$ ) were calculated following Kiran et al. (2013).

Chl fluorescence was measured on the same leaves used for gas-exchange measurements in dark- and light-adapted leaves by using a portable Chl fluorometer (JUNIOR$P A M, W A L Z$, Germany) at midday $(12: 00 \mathrm{~h})$. Different parameters, such as minimal fluorescence $\left(\mathrm{F}_{0}\right)$, maximal fluorescence $\left(F_{m}\right)$, variable fluorescence $\left(F_{v}=F_{m}-F_{0}\right)$, and 
maximum photochemical efficiency of PSII $\left(\mathrm{F}_{\mathrm{v}} / \mathrm{F}_{\mathrm{m}}\right)$ were measured in 20-min dark-adapted leaves (Maxwell and Johnson 2000). In light-adapted leaves at a PPFD of $420 \mu \mathrm{mol} \mathrm{m} \mathrm{m}^{-2} \mathrm{~s}^{-1}$, steady-state fluorescence yield $\left(\mathrm{F}_{\mathrm{s}}\right)$, maximal fluorescence $\left(\mathrm{F}_{\mathrm{m}}{ }^{\prime}\right)$, and minimal fluorescence $\left(\mathrm{F}_{0}{ }^{\prime}\right)$ were measured. Quenching value due to nonphotochemical dissipation (NPQ), the coefficient for photochemical quenching $\left(\mathrm{q}_{\mathrm{P}}\right)$, and effective quantum yield of PSII photochemistry ( $\left.\Phi_{\text {PSII }}\right)$ were also calculated (Maxwell and Johnson 2000). The electron transport rate (ETR) was measured by the light-induction curve with different PAR following the software supplied by the manufacturer.

Chl and carotenoid (Car) contents: After measurement of the Chl fluorescence, the same leaves were pooled together, finely chopped, and used for Chl and Car estimation. Fresh leaves of $100 \mathrm{mg}$ were placed in a $25-\mathrm{ml}$ capped-measuring tube containing $10 \mathrm{ml}$ of $80 \%$ cold acetone, and kept inside a refrigerator $\left(4^{\circ} \mathrm{C}\right)$ for $48 \mathrm{~h}$. The total $\mathrm{Chl}$ and Car were measured spectrophotometrically (Bio spectrophotometer, Eppendorff, Germany) by taking absorbance at 663, 645, and $470 \mathrm{~nm}$. The total Chl and Car content were calculated using the equations of Arnon (1949) and Lichtenthaler and Welburn (1983), respectively.

Relative water content (RWC), dry matter accumulation (DMA) and protein: For RWC, the leaflet of each species from the main shoot apex was collected and immediately weighed for taking the leaf fresh mass (LFM, $\mathrm{g})$, dipped in deionised water, and left in the dark for $48 \mathrm{~h}$.

\section{Results and discussion}

Variation in leaf gas exchange and photosynthetic pigments: Carbon balancing within the plant species is an important feature for climatic adaptability. Leaf photosynthesis and gas-exchange traits are directly linked to a carbon balance (Kondamudi et al. 2016). These features were compared in seven wild and one cultivated Dioscorea species. In the present study, wide variations were observed in different Dioscorea species for leaf gasexchange parameters (Table 1). There were significant differences between wild and cultivated Dioscorea species with regard to $P_{\mathrm{N}}$; the range of $P_{\mathrm{N}}$ in wild Dioscorea species, such as D. hamiltonii, D. pubera, and D. oppositifolia, were significantly higher than that of cultivated species (D. alata). Similarly, $g_{\mathrm{s}}$ and $E$ were also higher in some wild species than that of cultivated species of Dioscorea. Further, the WUE $\left(P_{\mathrm{N}} / E\right)$ and $\mathrm{CE}\left(P_{\mathrm{N}} / C_{\mathrm{i}}\right)$ varied significantly among the wild and cultivated Dioscorea species (Table 1). The wild Dioscorea species, such as D. hamiltonii, D. pubera, and D. oppositifolia, showed significantly higher WUE and CE than that of cultivated species (D. alata). There have been several reports that wild species are associated with higher leaf $P_{\mathrm{N}}$ and can contribute genes for improving complex traits,
Afterwards, they were again weighed to measure the leaf turgid mass (LTM, g) and then placed in an oven at $70^{\circ} \mathrm{C}$ for $48 \mathrm{~h}$ to determine the leaf dry mass (LDM). The relative water content (RWC) of the leaf was calculated according to Abenavoli et al. (2016).

$$
\mathrm{RWC}[\%]=(\mathrm{LFM}-\mathrm{LDM}) /(\mathrm{LTM}-\mathrm{LDM}) \times 100
$$

The leaf DMA was calculated by the following formula

$$
\mathrm{DMA}[\%]=(\mathrm{LDM} / \mathrm{LFM}) \times 100
$$

For leaf protein estimation, fresh leaf material of $0.5 \mathrm{~g}$ was homogenized in $10 \mathrm{ml}$ of $50 \mathrm{mM}$ potassium phosphate buffer ( $\mathrm{pH} 7.8)$. The homogenate was centrifuged at $0-4^{\circ} \mathrm{C}$ at $12,000 \mathrm{rpm}$ for $15 \mathrm{~min}$ and the supernatant was used for determining of protein content following Lowry et al. (1951).

Statistical analysis: Differences between various parameters were compared by one-way analysis of variance (ANOVA) using CROPSTAT (International Rice Research Institute, Philippines) software. The statistical significance of the parameter means was determined by performing the Fisher's least significance difference ( $L S D)$ test. The standard deviations (SD) and multiple correlation analysis were done by Microsoft Excel 2007. The similarity index in different Dioscorea species was constructed by dendogram using different photosynthetic parameters and was measured through paired group (UPGMA) by Bray-Curtis similarity index using PAST-3 (Palaeontological Statistics) software.

such as high biomass and abiotic stress tolerance (Placido et al. 2013). This adds important information regarding leaf photosynthetic performance of some wild Dioscorea species under the prevailing environmental conditions.

Leaf pigments reflect photosynthetic properties of the plants, as they indicate the amount of light-harvesting capacity (Elfeky et al. 2007). Car provide photoprotective functions in photosynthesis, are integral constituents of the photosystems, mostly in xanthophylls. Car protect $\mathrm{Chl}$ and thylakoid membranes from the damage by absorbed energy, photooxidation (Bailey et al. 2004). The significant difference in $\mathrm{Chl}$ and Car contents was observed between the Dioscorea species (Table 1). The wild species, such as D. hamiltonii, D. pubera, and D. oppositifolia, showed significantly more $\mathrm{Chl}$ and Car in comparison to other species including cultivated $D$. alata.

Variations in leaf PSII activity and electron transport rate: In addition, $\mathrm{Chl}$ fluorescence measurement helps to assess the intrinsic photosynthetic performance of plants, which provides important information regarding PSII, reflecting actual performance of the plant in prevalent environmental conditions (Batra et al. 2016). The leaf PSII 


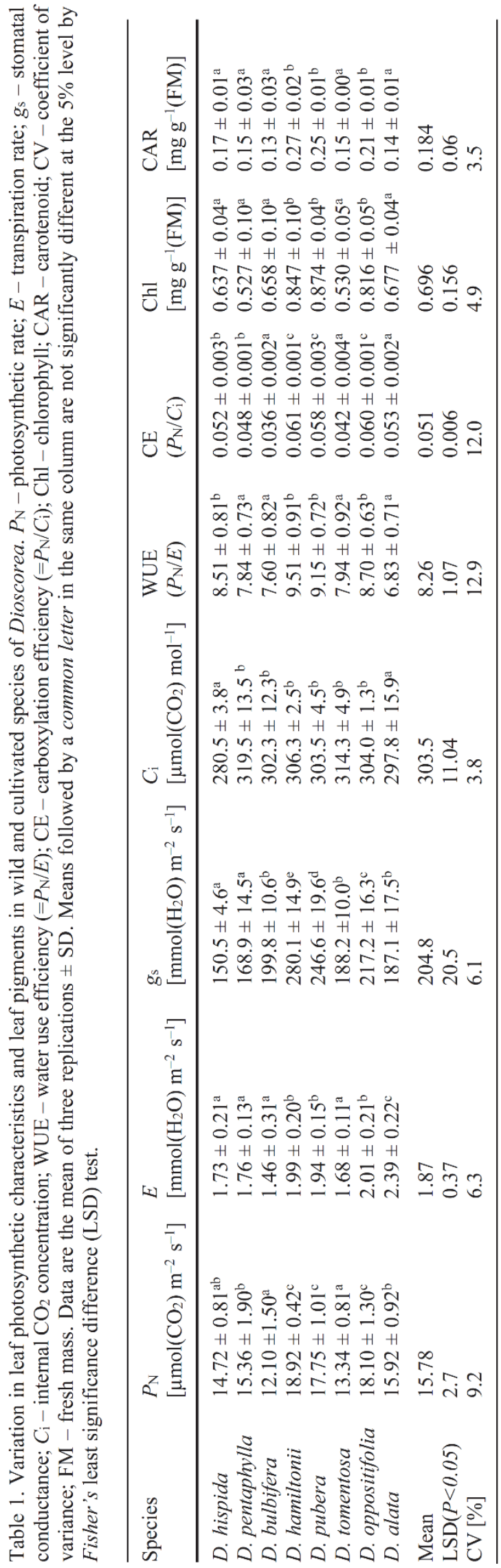

activity of different Dioscorea species was studied by measuring different $\mathrm{Chl}$ fluorescence parameters. The $\mathrm{F}_{0}$, $\mathrm{F}_{\mathrm{m}}, \mathrm{F}_{\mathrm{v}} / \mathrm{F}_{\mathrm{m}}, \Phi_{\mathrm{PSII}}, \mathrm{NPQ}$, and $\mathrm{q}_{\mathrm{P}}$ are widely used Chl fluorescence parameters in plant physiology studies (Murchie and Lawson 2013). These parameters were significantly different between the species (Table 2). In the present study, wild species, such as $D$. hamiltonii, D. pubera, and D. oppositifolia, showed better PSII activity under prevalent environmental conditions as evident from the higher value of $\mathrm{F}_{0}, \mathrm{~F}_{\mathrm{m}}, \mathrm{F}_{\mathrm{v}} / \mathrm{F}_{\mathrm{m}}, \Phi_{\text {PSII }}$, and $\mathrm{q}_{\mathrm{P}}$ with less NPQ compared to the cultivated species (Table 2). The result showed that most of the plants were healthy as maximal photochemical efficiency of PSII was in the range of $0.707-0.783$ with high $\mathrm{q}_{\mathrm{P}}$ and very low NPQ value (Pinnola et al. 2013). The parameter $\Phi_{\mathrm{PSI}}$ gives an approximation of the proportion of absorbed energy being used for photochemistry at a given point in time and reflects the degree of adaptation of plant to its environment (Maxwell and Johnson 2000). Additionally, it has been demonstrated that genotypic differences exist in the composition of NPQ (Müller et al. 2001), which relates to the ecology of the plant. Therefore, our result reflected that the degree of adaptation to prevailing environment in some wild species, such as D. hamiltonii, D. pubera, and D. oppositifolia, was greater than that of cultivated species.

Light-response curves (LCs) reflect intrinsically photosynthetic capacity of plants (Lüttge et al. 2007) and can be used to assess the performance of the plants (Batra et al. 2016). In the present study, a different range of PAR [65-820 $\mu \mathrm{mol}$ (photon) $\mathrm{m}^{-2} \mathrm{~s}^{-1}$ ] was given to measure the ETR of selected Dioscorea species for determining the PAR saturation. It was found that with increase in PAR range, the ETR also gradually increased. Maximum ETR was observed in D. hamiltonii, D. pubera, and D. oppositifolia and showed better photochemical activity in the prevalent environmental conditions compared to the cultivated species D. alata (Fig. 1).

Variations in leaf dry matter accumulation (DMA), relative water content (RWC) and protein: The process of biomass production under changing climate is one of requirements for sustaining global food production (Zhu et al. 2008, Kajala et al. 2011). Biomass production is mainly a net product of photosynthetic carbon assimilation (Makino 2011). In addition to the leaf $P_{\mathrm{N}}$, some of the wild species, such as D. hamiltonii, D. pubera, and D. oppositifolia, showed significantly more DMA (\%) compared to the cultivated species (Fig. 2A). Higher source size and enhanced photosynthesis was found to be a basis of the increased DMA in wild Dioscorea species as reported in other crops (Hayat et al. 2012). Some wild species, such as D. hamiltonii, D. pubera, and D. oppositifolia, showed significantly higher leaf RWC and protein content if compared to the cultivated species D. alata (Fig. 2B,C). At the same time, the $g_{\mathrm{s}}$ and WUE were also higher in these species than in others (Table 1). In spite of this, not only they preserved their water content effectively but also their 
Table 2. Variation in leaf chlorophyll fluorescence parameters in wild and cultivated Dioscorea species. $\mathrm{F}_{0}-$ minimum fluorescence yield obtained with dark-adapted leaf; $F_{m}-$ maximum Chl fluorescence yield obtained with dark-adapted leaf; $F_{v} / F_{m}-$ maximal photochemical efficiency of PSII; NPQ - nonphotochemical quenching; qp - photochemical quenching; ФPSII - effective quantum yield of PSII photochemistry; CV - coefficient of variance. Data are the mean of three replications \pm SD. Means followed by a common letter in the same column are not significantly different at the 5\% level by Fisher's least significance difference (LSD) test.

\begin{tabular}{lllllll}
\hline Species & $\mathrm{F}_{0}$ [rel.] & $\mathrm{F}_{\mathrm{m}}$ [rel.] & $\mathrm{F}_{\mathrm{v}} / \mathrm{F}_{\mathrm{m}}$ [ratio] & $\Phi_{\text {PSII }[\text { ratio] }}$ & qP [rel.] & NPQ [rel.] \\
\hline D. hispida & $453.5 \pm 30.9^{\mathrm{a}}$ & $1,810 \pm 194^{\mathrm{a}}$ & $0.709 \pm 0.021^{\mathrm{a}}$ & $0.131 \pm 0.021^{\mathrm{a}}$ & $0.298 \pm 0.028^{\mathrm{a}}$ & $1.81 \pm 0.14^{\mathrm{b}}$ \\
D. pentaphylla & $458.5 \pm 23.5^{\mathrm{a}}$ & $1,892 \pm 175^{\mathrm{a}}$ & $0.705 \pm 0.012^{\mathrm{a}}$ & $0.129 \pm 0.030^{\mathrm{a}}$ & $0.294 \pm 0.017^{\mathrm{a}}$ & $1.43 \pm 0.13^{\mathrm{b}}$ \\
D. bulbifera & $422.0 \pm 19.4^{\mathrm{a}}$ & $1,770 \pm 111^{\mathrm{a}}$ & $0.711 \pm 0.022^{\mathrm{a}}$ & $0.127 \pm 0.018^{\mathrm{a}}$ & $0.334 \pm 0.021^{\mathrm{a}}$ & $2.49 \pm 0.26^{\mathrm{c}}$ \\
D. hamiltonii & $578.0 \pm 34.3^{\mathrm{b}}$ & $1,951 \pm 108^{\mathrm{b}}$ & $0.783 \pm 0.012^{\mathrm{b}}$ & $0.191 \pm 0.014^{\mathrm{b}}$ & $0.377 \pm 0.020^{\mathrm{b}}$ & $1.03 \pm 0.03^{\mathrm{a}}$ \\
D. pubera & $567.0 \pm 41.3^{\mathrm{b}}$ & $2,121 \pm 170^{\mathrm{b}}$ & $0.780 \pm 0.011^{\mathrm{b}}$ & $0.183 \pm 0.033^{\mathrm{b}}$ & $0.366 \pm 0.027^{\mathrm{b}}$ & $1.02 \pm 0.05^{\mathrm{a}}$ \\
D. tomentosa & $481.0 \pm 31.9^{\mathrm{a}}$ & $2,119 \pm 100^{\mathrm{b}}$ & $0.738 \pm 0.011^{\mathrm{a}}$ & $0.097 \pm 0.017^{\mathrm{a}}$ & $0.291 \pm 0.024^{\mathrm{a}}$ & $1.48 \pm 0.12^{\mathrm{b}}$ \\
D. oppositifolia & $581.5 \pm 33.5^{\mathrm{b}}$ & $2,175 \pm 160^{\mathrm{b}}$ & $0.783 \pm 0.013^{\mathrm{b}}$ & $0.186 \pm 0.034^{\mathrm{b}}$ & $0.372 \pm 0.030^{\mathrm{b}}$ & $1.04 \pm 0.13^{\mathrm{a}}$ \\
D. alata & $439.5 \pm 27.0^{\mathrm{a}}$ & $1,705 \pm 136^{\mathrm{a}}$ & $0.742 \pm 0.010^{\mathrm{a}}$ & $0.159 \pm 0.021^{\mathrm{a}}$ & $0.335 \pm 0.025^{\mathrm{b}}$ & $1.48 \pm 0.14^{\mathrm{b}}$ \\
Mean & 497.6 & $1,942.9$ & 0.744 & 0.151 & 0.333 & 1.45 \\
LSD $(P<0.05)$ & 46.3 & 210 & 0.035 & 0.057 & 0.044 & 0.41 \\
CV [\%] & 15.9 & 18.7 & 5.7 & 5.9 & 5.5 & 5.1 \\
\hline
\end{tabular}

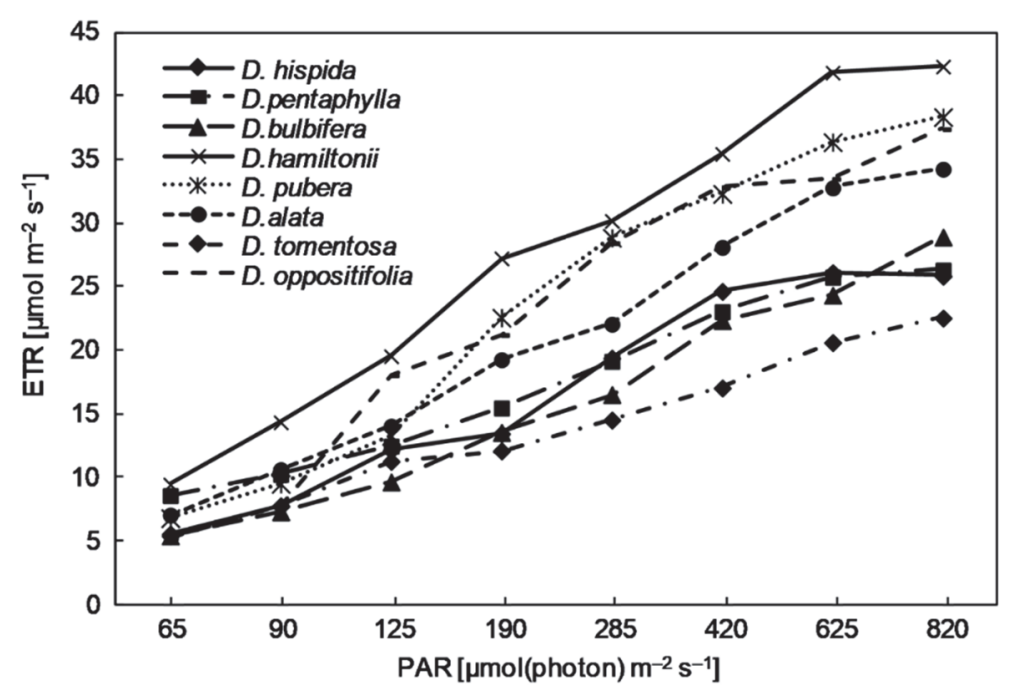

Fig. 1. Electron transport rate (ETR) in different wild and cultivated species of Dioscorea under different photosynthetic active radiation (PAR). Data are the mean of three replications $(n=3)$.

WUE was high because of their leaf morphology and architecture. This showed some wild species maintaining the leaf vitality and plasticity more efficiently under prevalent environmental condition than the cultivated species (Türkan et al. 2005).

Variation in tuber yield: Very little information is available on the yield potential of wild Dioscorea species and many wild species could not be domesticated primarily due to their poor yield and tubers of inferior quality (Behera et al. 2009). But in the present study, some of the wild species, such as D. pubera, D. oppositifolia, and $D$. hamiltonii, showed significantly higher tuber yield compared to the cultivated species D. alata (Fig. 3). Although, the wild species D. tomentosa showed better leaf photosynthetic performance in the present study, the yield was very low. This is because higher vegetative growth in a tuber crop requires more photosynthates for maintenance of vegetative parts thus resulting in the poor tuber yield (Behera et al. 2009). The ability to form tubers is dependent on the genetics of the variety (Martin 1978) and is affected by environmental factors, such as day length, temperature, and cultivation practices (King and Risimeri 1992). However, the yield of tuber is not the only criterion for selection of species, rather the quality of the tuber plays an important role for domestication.

Correlation: Relationships between leaf photosynthetic parameters and dry matter accumulation and tuber yield in different Dioscorea species were studied by multiple correlation analysis (Table 3 ). The results revealed that the $P_{\mathrm{N}}$ was not significantly influenced by leaf $\mathrm{Chl}$ and Car contents. A significant positive correlation between $P_{\mathrm{N}}$ and $E, g_{\mathrm{s}}, \mathrm{CE}, \mathrm{WUE}, \mathrm{F}_{\mathrm{v}} / \mathrm{F}_{\mathrm{m}}, \Phi_{\mathrm{PSII}}$, and $\mathrm{q}_{\mathrm{P}}$ was observed, whereas, leaf $P_{\mathrm{N}}$ was negatively correlated with $C_{\mathrm{i}}, \mathrm{F}_{0}$, and NPQ. This result indicated that the observed variations in 


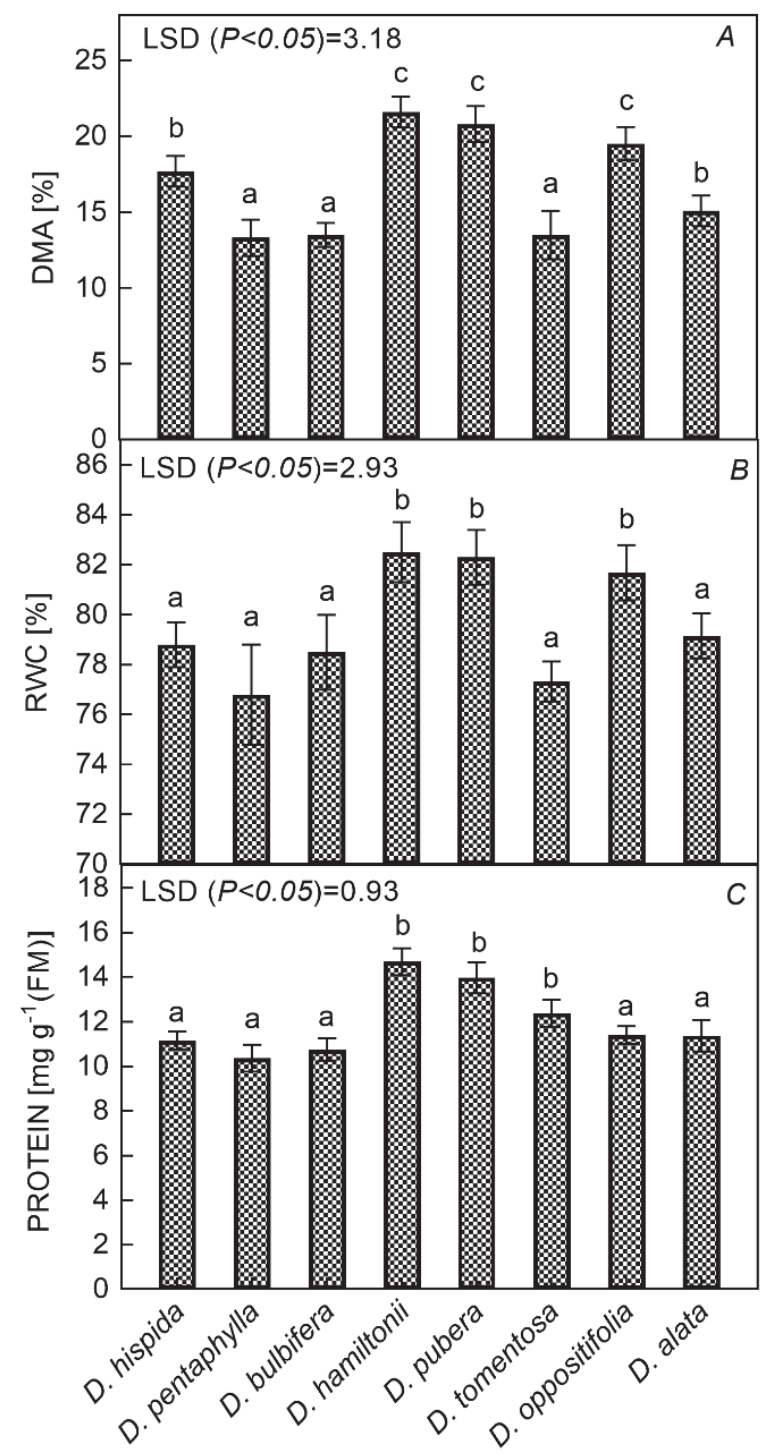

Fig. 2. Leaf dry matter accumulation (DMA), relative water content (RWC), and protein content in different wild and cultivated species of Dioscorea. Data are the means of three replications and bars indicate the standard deviation of the means $(n=3)$. Means followed by a common letter are not significantly different at the 5\% level by Fisher's least significance difference (LSD) test.

$P_{\mathrm{N}}$ in different Dioscorea species were not based on the pigment content, but it was related to the PSII photochemical activity and leaf CE and WUE as it has been reported earlier in other crops (Yeo et al. 1994, Kiran et al. 2013, Haritha et al. 2017). Significant association between leaf $P_{\mathrm{N}}$ with light saturation and carboxylation efficiency was reported in many crops (Ding et al. 2014). The leaf $\mathrm{Chl}$ content is an important physiological trait, closely associated with photosynthesis, and used to predict a yield potential (Teng et al. 2004, Abhilash Joseph et al. 2014). But in the present study, Chl was not a determinant for leaf photosynthesis, DMA, and yield in Dioscorea species under prevalent environmental conditions. Further, leaf $P_{\mathrm{N}}$ showed significant positive correlation with DMA, which supports the previous reports of Evans (2013) and Puteh et al. (2014) for increased biomass in other crops. However, in the present study, no association between $P_{\mathrm{N}}$ and the tuber yield was observed, as it has been reported in other crops, such as rice, wheat, soybean, sugarcane, cotton, and sunflower; thus, the higher yield was not associated with leaf $P_{\mathrm{N}}$ (Richards 2000).

Variations among Dioscorea species: Cluster analysis based on the Bray-Curtis paired linkage revealed the percentage of similarity in leaf photosynthetic parameters among wild and cultivated Dioscorea species presented in Fig. 4. The dendrogram showing the similarity formed two clusters, such as D. pubera, D. oppositifolia, and D. hamiltonii, which are in one cluster having $95.6 \%$ similarity.

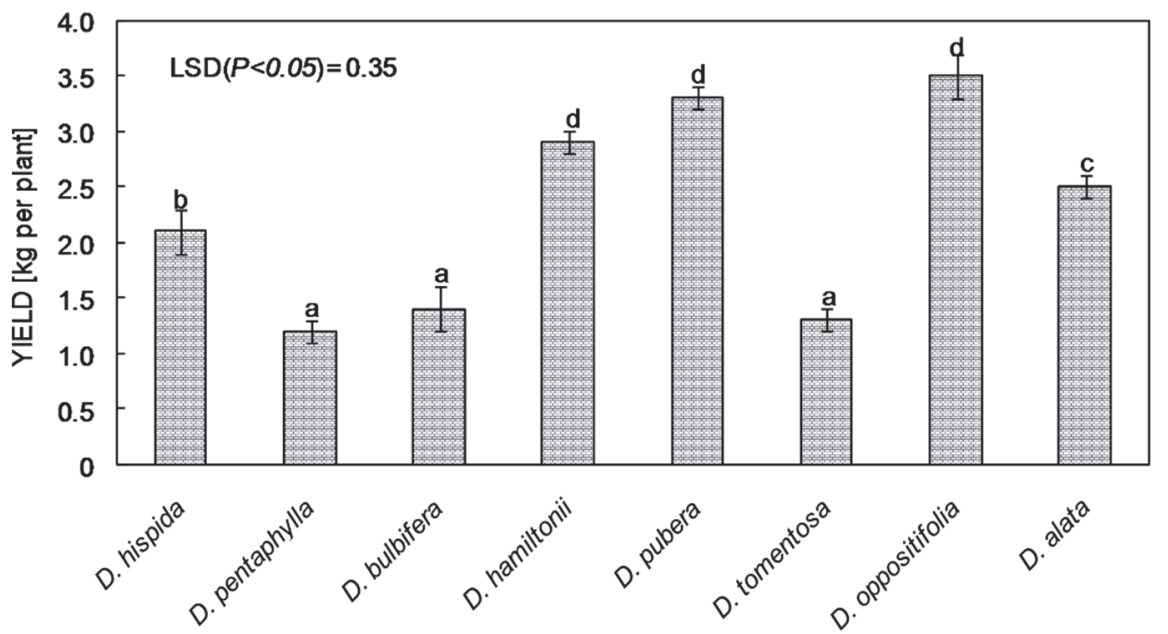

Fig. 3. Fresh tuber yield [kg per plant] in different wild and cultivated species of Dioscorea. Data are the mean of three replications and bars indicate the standard deviation of the means $(n=3)$. Means followed by a common letter are not significantly different at the $5 \%$ level by Fisher's least significance difference (LSD) test. 


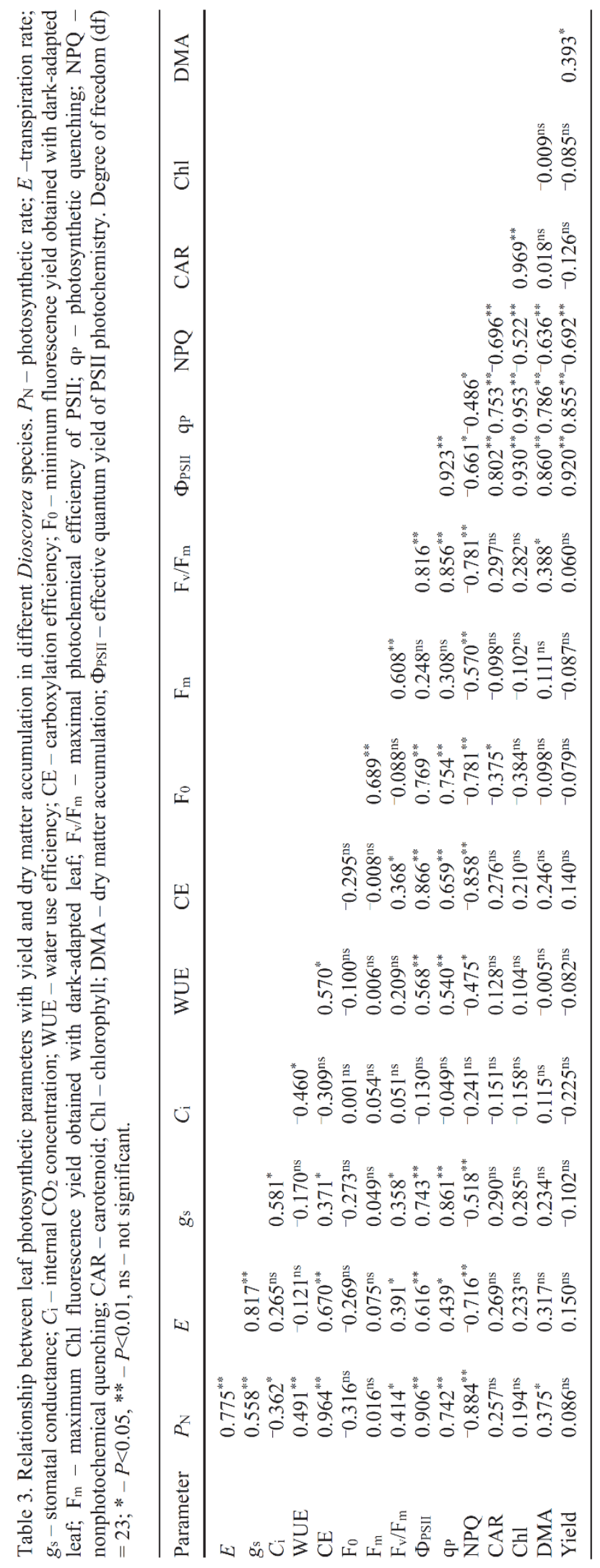




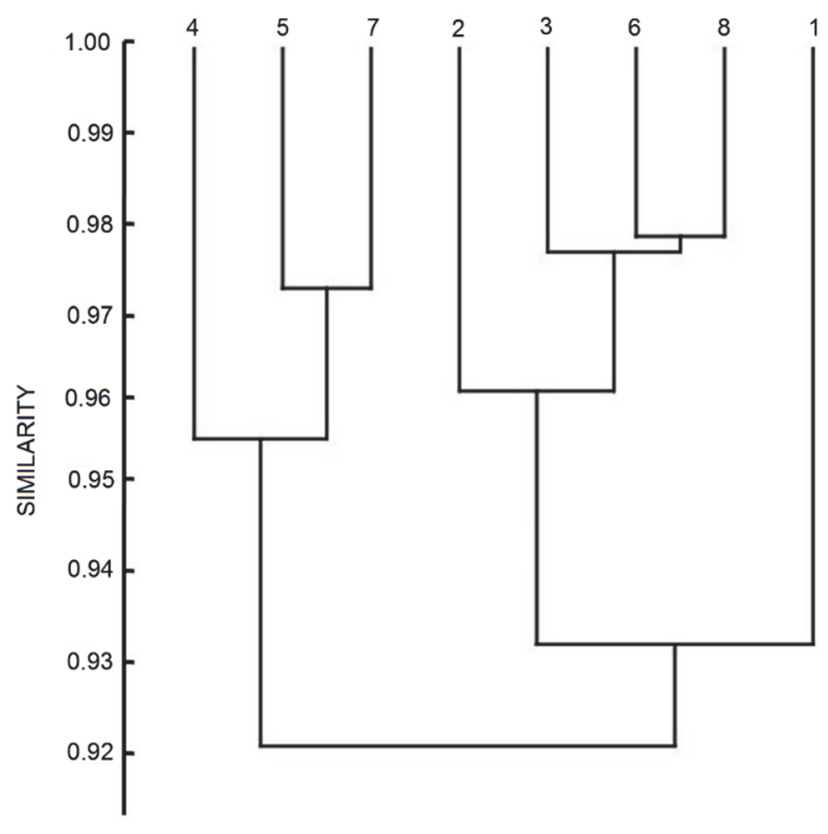

Fig. 4. Dendrogram showing the percentage of similarity between the Dioscorea species constructed using different photosynthetic parameters. Data are the mean of three replications $(n=3)$. $1-D$. hispida; $2-D$. pentaphylla; $3-D$. bulbifera; $4-D$. hamiltonii; 5 - D. pubera; $6-$ D. tomentosa; $7-D$. oppositifolia; $8-$ D. alata.

\section{References}

Abenavoli M.R., Leone M., Sunseri F. et al.: Root phenotyping for drought tolerance in Bean landraces from Calabria (Italy). - J. Agron. Crop. Sci. 202: 1-12, 2016.

Abhilash Joseph.E., Radhakrishnan V.V., Chandramohanan K.T., Mohanan K.V.: Reduction of major photosynthetic pigments under salinity stress in some native rice cultivars of North Kerala, India. - Int. J. Recent Sci. Res. 5: 1602-1611, 2014.

Aighewi B.A., Ekanayake I.J.: In situ chlorophyll fluoresence and related growth of Guinea yam at different ages. - Trop. Sci. 44: 201-206, 2004.

Amanze N.J., Agbo N.J., Eke-Okoro O.N., Njoku D.N.: Selection of yam seeds from open pollination for adoption in yam (Dioscorea rotundata Poir) production zones in Nigeria. J. Plant Breed. Crop. Sci. 3: 68-73, 2011.

Arnon D.I.: Copper enzymes in isolated chloroplasts, polyphenol oxidase in Beta vulgaris. - Plant Physiol. 24: 1-15, 1949.

Bailey S., Horton P., Walters R.G.: Acclimation of Arabidopsis thaliana to the light environment: The relationship between photosynthetic function and chloroplast composition. - Planta 218: 793-802, 2004.

Batra N.G., Kumari N., Sharma V.: Photosynthetic performance of Ocimum sanctum morphotypes in a semiarid region. - J. Herbs Spices Med. Plants 22: 211-224, 2016.

Behera K.K., Maharana T., Sahoo S., Prusti A.: Biochemical quantification of protein, fat, starch, crude fiber, ash and dry matter content in different collection and greater yam (Dioscorea alata L.) found in Orissa. - Nat. Sci. 7: 24-32, 2009.

Below E.F.: Nitrogen metabolism and crop productivity. - In:
The D. bulbifera, D. pentaphylla, D. tomentosa, and $D$. hispida were in a separate cluster with the cultivated species D. alata and showed $93.7 \%$ similarity. The species which are within the same cluster are unique as they showed similar leaf photosynthetic traits. The wild species, such as D. oppositifolia, D. hamiltonii, and D. pubera, had superior photosynthetic efficiency compared to the cultivated species D. alata under prevailing environmental conditions.

Conclusion: The present study on comparative ecophysiological traits between wild and cultivated species of Dioscorea revealed that some wild species recorded superior photosynthetic efficiency and yield in comparison to the cultivated species. Environmental adaptation in wild Dioscorea species seems to be associated with leaf photosynthetic gas-exchange capacity, PSII activity leading to the better tuber yield. Taken together, the wild species, such as D. oppositifolia, D. hamiltonii, and D. pubera, had superior photosynthetic efficiency and tuber yield potential in comparison to the cultivated $D$. alata, which may determine the ecological dominance and the adaptability of the wild species under the future climate change. Further research is aimed to elucidate the genetic diversity in relation to leaf phenotyping and the use of superior wild Dioscorea species for crop improvement programs under a changing climate.

Pessarakli M. (ed.): Handbook of Plant and Crop Physiology. Pp. 385-406. University of Arisona, Tucson, Arizona 2001.

Dansi A., Mignouna H.D., Zoundjihékpon J. et al:: Morphological diversity, cultivar groups and possible descent in the cultivated yams (Dioscorea cayenensis-Dioscorea rotundata complex) of Benin Republic. - Genet. Resour. Crop Ev. 46: 371-388, 1999.

Ding Z.S., Li T., Zhu X.G. et al.: Three photosynthetic patterns characterized by cluster analysis of gas exchange data in two rice populations. - Crop. J. 2: 22-27, 2014.

Dudeja S.S., Chaudhary P.: Fast chlorophyll fluorescence transient and nitrogen fixing ability of chickpea nodulation variants. - Photosynthetica 43: 253-259, 2005.

Edison S., Unnikrishnan M., Vimala B. et al.: Biodiversity of tropical tuber crops in India. - In: Edison S. (ed.): NBA Scientific Bulletin No. 7. Pp. 60. National Biodiversity Authority of India, Chennai, Tamilnadu, India 2006.

Elfeky S.S., Osman M.E.H., Hamada S.M., Hasan A.M.: Effect of salinity and drought on growth criteria and biochemical analysis of Catharanthus roseus shoot. - Int. J. Bot. 3: 202207, 2007.

Evans J.R.: Improving photosynthesis. - Plant. Physiol. 162: 1780-1793, 2013.

Gupta S.K., Prakash J., Srivastava S.: Validation of claim of Tulsi, Ocimum sanctum L. as a medicinal plant. - Ind. J. Exp. Biol. 40: 765-773, 2002.

Haritha G., Vishnukiran T., Yugandhar P. et al.: Introgressions from Oryza rufipogon increase photosynthetic efficiency of KMR3 rice lines. - Rice Sci. 24: 85-96, 2017.

Hayat S., Khalique G., Irfan M. et al.: Physiological changes 
induced by chromium stress in plants: an overview. Protoplasma 249: 599-611, 2012.

Kajala K., Covshoff S., Karki S. et al.: Strategies for engineering a two-celled $\mathrm{C} 4$ photosynthetic pathway into rice. - J. Exp. Bot. 62: 3001-3010, 2011.

Kao W.Y., Tsai T.T., Shih C.N.: Photosynthetic gas exchange and chlorophyll a fluorescence of three wild soybean species in response to $\mathrm{NaCl}$ treatments. - Photosynthetica 41: 415-419, 2003.

King G.A., Risimeri J.B.: Effects of planting density, height of staking and variety on yield and yield components of the lesser yam (Dioscorea esculenta). - Trop. Agric. 69: 129-132, 1992.

Kiran T.V., Rao Y.V., Subrahmanyam D. et al.: Variation in leaf photosynthetic characteristics in wild rice species. Photosynthetica 51: 350-358, 2013.

Kondamudi R., Swamy K.N., Rao Y.V. et al.: Gas exchange, carbon balance and stomatal traits in wild and cultivated rice (Oryza sativa L.) genotypes. - Acta Physiol. Plant. 38: 160, 2016.

Kouakou M.D., Dabonne S., Guehi, T., Kuoame L.P.: Effects of post-harvest storage on some biochemical parameters of different parts of two yams species (Dioscorea spp). - Afr. J. Food Sci. 1: 1-9, 2010.

Kumar S., Parida A.K., Jena P.K.: Ethno-Medico-Biology of Bān-Aālu (Dioscorea species): A neglected tuber crops of Odisha, India. - Int. J. Pharm. Life Sci. 4: 3143-3150, 2013.

Lichtenthaler H.K., Wellburn A.R.: Determinations of total carotenoids and chlorophylls $a$ and $b$ of leaf extracts in different solvents. - Biochem. Soc. T. 11: 591-592, 1983.

Lowry O.H., Rosebrough N.J., Farr A.L., Randall R.J.: Protein measurement with the folin phenol reagent. - J. Biol. Chem. 193: 265-275, 1951.

Lüttge U., Scarano F.R.: Synecological comparisons sustained by ecophysiological fingerprinting of intrinsic photosynthetic capacity of plants as assessed by measurements of light response curves. - Rev. Bras. Bot. 30: 355-364, 2007.

Makino A.: Photosynthesis, grain yield, and nitrogen utilization in rice and wheat. - Plant. Physiol. 155: 125-129, 2011.

Martin F.W., Degras L.: Tropical Yams and their Potential. Part. 6. Minor Cultivated Dioscorea species. Agricultural Handbook No. 538. Pp. 23. Science and education administration, U.S. Department of Agriculture (USDA) and USAID, Washington, USA 1978.

Mathur S., Kalaji H.M., Jajoo A.: Investigation of deleterious effects of chromium phytotoxicity and photosynthesis in wheat plant. - Photosynthetica 54: 185-192, 2016.

Maxwell K., Johnson G.N.: Chlorophyll fluorescence - a practical guide. - J. Exp. Bot. 51: 659-668, 2000.

Mishra S., Chaudhury S.S.: Ethnobotanical flora used by four major tribes of Koraput, Odisha, India. - Genet. Resour. Crop Ev. 59: 793-804, 2012.

Mishra S., Swain S., Chaudhury S., Ray S.: Wild edible tubers
(Dioscorea spp.) and their contribution to the food security of tribes of Jeypore tract, Orissa, India. - PGR News. 156: 63-67, 2011.

Müller P., Li X.P., Niyogi K.K.: Non-photochemical quenching. A response to excess light energy. - Plant Physiol. 125: 15581566, 2001.

Murchie E.H., Lawson T.: Chlorophyll fluorescence analysis: a guide to good practice and understanding some new applications. - J. Exp. Bot. 64: 3983-3998, 2013.

Ngo Ngwe M.F.S., Omokolo D.N., Joly S.: Evolution and phylogenetic diversity of yam species (Dioscorea spp.): Implication for conservation and agricultural practices. - PLoS ONE 10: e145364, 2015

Padhan B., Panda D.: Wild tuber species diversity and its ethnomedicinal use by tribal people of Koraput district of Odisha, India. - J. Nat. Prod. Resour. 2: 33-36, 2016.

Pinnola A., Dall'Osto L., Gerotto C. et al.: Zeaxanthin binds to light-harvesting complex stress-related protein to enhance nonphotochemical quenching in Physcomitrella patens. - Plant Cell 25: 3519-3534, 2013.

Placido D., Campbell M.T., Folsom J.J. et al.: Introgression of novel traits from a wild wheat relative improves drought adaptation in wheat (Triticum aestivum). - Plant. Physiol. 161: 1806-1819, 2013.

Puteh A.B., Mondal M.M.A., Ismail M.R., Latif M.A.: Grain sterility in relation to dry mass production and distribution in rice (Oryza sativa L.). - BioMed. Res. Int. 2014: 302179, 2014.

Richards R.A.: Selectable traits to increase crop photosynthesis and yield of grain crops. - J. Exp. Bot. 51: 447-458, 2000.

Rodríguez-Montero W.: Crop Physiology of the Greater Yam (Dioscorea alata). Pp. 151. Ulrich E. Grauer, Stuttgart 1997.

Sayed O.H.: Chlorophyll fluorescence as a tool in cereal crop research. - Photosynthetica 41: 321-330, 2003.

Souza R.P., Machadoa E.C., Silva I.A.B. et al.: Photosynthesis gas exchange, chlorophyll fluorescence and some associated metabolic changes in cowpea (Vigna unguiculata) during water stress and recovery. - Environ. Exp. Bot. 51: 45-56, 2004.

Teng S., Qian Q., Zeng D.L. et al.: QTL analysis of leaf photosynthetic rate and related physiological traits in rice (Oryza sativa L.). - Euphytica 135: 1-7, 2004.

Türkan I., Bor M., Özdemir F., Koca H.: Differential responses of lipid peroxidation and antioxidants in the leaves of drought tolerant $P$. acutifolius Gray and drought sensitive $P$. vulgaris L. subjected to polyethylene glycol mediated water stress. Plant Sci. 168: 223-231, 2005.

Yeo M.E., Yeo A.R., Flowers T.J.: Photosynthesis and photorespiration in the genus Oryza. - J. Exp. Bot. 45: 553-560, 1994.

Zhu X.G., Long S.P., Ort D.R.: What is the maximum efficiency with which photosynthesis can convert solar energy into biomass. - Curr. Opin. Biotech. 19: 153-59, 2008. 